\title{
ROLE OF BIO-FERTILIZERS IN IMPROVEMENT ROSEMARY PRODUCTIVITY UNDER WATER-DEFICIT CONDITION
}

\author{
K.A. Hammam, E.A. Eisa and Reem H. Ibrahim \\ Medicinal and Aromatic Plants Research Department, Horticulture Research Institute, Agric. Res. \\ Center, Giza, Egypt
}

\begin{abstract}
This study was carried out during the two successive growing seasons of 2018/2019 and 2019/2020 at the Farm of Ali Mubarak, South Tahrir, El-Bahira Governorate, Horticulture Research Station. Egypt, aiming to study the impact of some bio-fertilizers (Mycorrhiza, Algae, and PGPR) combined with 3 levels of irrigation (800, 1200 , and $1600 \mathrm{~m}^{3} /$ fed treatments and their interactions on vegetative growth, essential oil \%, essential oil components, $\mathrm{N}, \mathrm{P}, \mathrm{K} \%$, and proline content of rosemary (Rosmarinus officinalis L.) plant grown in a sandy soil. The obtained results could be summarized as follows; a significant increase in plant height, number of branches, and fresh and dry weights per plant were recorded with irrigation at 1200 $\mathrm{m}^{3} /$ fed. On the other hand, the highest oil percentages and oil yield/ plant resulted under the effect of irrigation at $800 \mathrm{~m}^{3} / \mathrm{fed}$ biofertilizer treatments also, increased vegetative growth parameters i.e., plant height, number of branches, herb fresh and dry weights/ plant and oil percentage, and yield/plant. Irrigation at the rate of $1200 \mathrm{~m}^{3} / \mathrm{fed}$, and PGPR alone or their combination resulted in the highest values of the above-mentioned traits (plant growth, parameters). However, the combination between irrigation at $800 \mathrm{~m}^{3} / \mathrm{fed}$ and PGPR showed the highest values of oil percentage and oil yield/plant. The N, P and K\% in dried herb recorded their higher values with medium irrigation, i.e., at the rate $1200 \mathrm{~m}^{3}$ in both cuts. Also, the results showed that there was a steady significant increase in proline content due to decreasing the irrigation rate. This investigation supports the application of naturallyoccurring plant growth promoting rhizobacteria (PGPR) and microorganism to advance plant development and sustainable option for farmers under deficit water to maximize the yield of rosemary plant.
\end{abstract}

Scientific J. Flowers \& Ornamental Plants, 8(1):135-151 (2021).

Received:

$1 / 2 / 2021$

Accepted:

$15 / 2 / 2021$

Corresponding author: K.A. Hammam drkhaled033@gmail.com

Key words: rosemary, irrigation, bio-fertilizers, essential oil and proline.

\section{INTRODUCTION}

Rosemary (Rosmarinus officinalis, L.) of the family Lamiaceae is one of the most important flavors, sweet-smelling, and therapeutic plants that broadly used the world over to obtain essential oil which can be used in cosmetics, perfumes, and pharmaceutical industries (Miguel et al.,
2007). Rosemary is local to the Mediterranean areas. Subsequently, it well develops all during the time under Egyptian conditions. The plant was accounted for to have therapeutic properties (Al-Sereitia et al., 1999) like anti-nervine spasmodic, carminative, and stimulant. The leaves also have hostile to oxidant properties and utilized for culinary purposes and very 


\section{K.A. Hammam et al.}

effective in control of Salmonella infection in meat products (Singh and Guleria, 2013).

Irrigation is one of the significant variables influencing plant development and yield. Furthermore, water resources should be utilized productively in light of the expanding rivalry of the restricted water resources between household, mechanical and farming utilization. Therefore, we aimed to search for different ways to conserve irrigation water and reduce losses, such as fertilizing with biological fertilizers that can supply the plant with its needs of nutrients in addition to obtaining a product free of chemical residues. In this respect, Hassan et al. (2013) revealed that deficit irrigation significantly reduced growth parameters and relative water content of rosemary plants compared to the control. The volatile oil percentage was increased; however, the yield was decreased by applying deficit irrigation treatments. Ekren et al. (2012) reported that water stress adversely influenced the plant tallness and the yield of basil plant. Despite what might be expected, the basic oil proportion of the plant expanded as the applied measure of water system water diminished. Water pressure positively affects essential oil constituents of the plant.

Bio-fertilizers are microbial arrangements containing living cells of various life forms (microscopic organisms, growths, cyanobacteria, and so forth.), which have the capacity to assemble plant supplements in soil from unusable to a usable structure through natural procedures. These composts are not hurtful to crops or different plants like the compound composts. They let the plants develop in a solid domain. The utilization of bio-fertilizers in the soil makes the plants healthy just as shield them from getting numerous sicknesses. They are likewise conditioned well-disposed and don't cause contamination of any kind (Sadhana, 2014).

Arbuscular Mycorrhizal (AM) fungi that belongs to the Phylum Glomeromycotan and symbiont with terrestrial plant roots enhance the growth, water and nutrient uptake.
Katalin and Nguyen (2019) mentioned that among beneficial microbes, Arbuscular Mycorrhizal fungi (AMF) are one of the most widespread symbiotic fungi colonizing the majority of agricultural plants. Besides, an enhancement in plant nutrition, AMF has been reported to improve plant performance under water restrictions.

Algae are photosynthetic organisms of a simple organization that live in water or very humid environments. Spirulina is a type of green-blue microalgae, belongs to the genus Arthrospira, which is cultivated in many parts of the world and has a great interest (Lopez-Padron, 2020).

Similarly, plant growth-promoting rhizobacteria (PGPR) are a group of naturally occurring beneficial soil bacteria that colonize with the plant root system and promote growth by triggering the production of growth-regulating substances and facilitate the plants' uptake of essential nutrients from the surrounding environments because it has the ability to hold water (Zahir et al., 2004; Nadeem et al., 2014). Besides, many of these rhizobacterial strains can also improve plant tolerance against drought and salinity and, therefore, enable plants to survive under environmental stress conditions (Mayak et al., 2004b; Nadeem et al., 2014; Sandhya et al., 2009; Zahir et al., 2008).

Application of biological fertilizers plays a remarkable role in improving vegetative growth, chemical composition and volatile oil compounds of rosemary plants developed under sandy soil condition. Inoculation with arbuscular mycorrhiza fungi (AMF), Bacillus megatherium strain (BM), Azospirillum brasilense strain (AZB) each alone or in mixture significantly increased rosemary growth parameters, chemical constituents and volatile oil parameters compared to the control (un inoculated plants). The mixed treatment of (AMF + BM + AZB) gave the maximum values in above mentioned parameters (Abeer et al., 2019). Combination of nitroxine + phosphate barvar-2 caused maximum value of plant 
height, leaf area, dry matter and FTBY in $90 \% \mathrm{FC}$ and essential oil percentage and yield in $60 \%$ FC of dragonhead (Dracocephalum moldavica L.). (Karimzadeh Asl et al., 2018). Abd ElWahab et al., 2016) reported that the highest significant increment for growth and yield characters of Origanum vulgare resulted from the treatment of algae extract + biofertilizer $+15 \mathrm{~m}^{3}$ compost as this combination treatment resulted in the highest mean value of oil yield ( $\mathrm{ml} / \mathrm{plant}$ ).

\section{MATERIALS AND METHODS}

This work was carried out during the two successive seasons of 2018/2019 and 2019/2020 at the Experimental Farm of Ali Mubarak, South Tahrir, El-Bahira Governorate, Horticulture Research Station to evaluate the role of and Arbuscular Mycorrhiza Fungi (AMF), Algae (Spirulina), and plant growth promoting rhizobacteria (PGPR) combined with 3 levels of irrigation treatments $\left(800,1200\right.$ and $1600 \mathrm{~m}^{3} / \mathrm{fed} \mathrm{in}$ improvement rosemary productivity under the water-deficit condition and their interactions in sandy soil.

\section{Plant materials:}

Terminal cuttings of rosemary plants (Rosmarinus officinalis, L.) were obtained from the Farm of Medicinal and Aromatic Plants Researches Department, El-Kanater El-Khayrea, and were cultivated under greenhouse at October $13^{\text {th }}$ in both seasons, and then the plants were transplanted in the experimental field at $20 \mathrm{~cm}$ apart on March $15^{\text {th }}$ and $18^{\text {th }}$ in the first and second seasons, respectively.

All plants were fertilized with the recommended doses of chemical fertilizers, i.e., calcium superphosphate was mixed with soil before transplanting at the rate of 200 $\mathrm{kg} / \mathrm{fed}$, potassium sulphate was applied at $100 \mathrm{~kg} / \mathrm{fed}$, nitrogen $(\mathrm{N})$ was applied at a rate of $200 \mathrm{~kg} / \mathrm{fed}$ using ammonium nitrate. Half dose of $\mathrm{N}$ and $\mathrm{K}$ were applied 15 days after transplanting and the second one was applied 15 days after the first cut.
The plants were harvested twice, the first cut was on June $10^{\text {th }}$ and the second one was on $20^{\text {th }}$ August in both seasons.

\section{The experimental design and treatments:}

The experimental design was split-plots, allocated in randomized complete blocks with three replicates. This experiment included 12 treatments arranged in a factorial experiment, main plots included three irrigation treatments $(800,1200$ and 1600 $\mathrm{m}^{3} / \mathrm{fed}$ ), and three bio-fertilizers treatments (PGPR, AMF and Algae) other than control, were arranged as subplots under drip irrigation system and their interactions. The experimental plots were $3.0 \times 2.50$ meters dimensions, with 3 rows at a distance of 60 $\mathrm{cm}$ between them and each plot represented an experimental unit.

Irrigation water was applied every three days by using a drip irrigation system. It was surface drip including an irrigation pump (50 $\mathrm{hp}$ ) connected to sand and screen filters and a fertilizer tank, control values, water flow meters, and pressure gauges. The conveying pipeline system consists of a $63 \mathrm{~mm}$ PVC main line connected to a $50.8 \mathrm{~mm}$ PVC submain line. The drip lateral lines of $16 \mathrm{~mm}$ diameter are connected to the sub-main line. Each lateral line $20 \mathrm{~m}$ long and spaced at 60 $\mathrm{cm}$ on the sub- main and is equipped with build-in emitters of $2 \mathrm{l} / \mathrm{h}$ discharge rate spaced at $30 \mathrm{~cm}$ on the lateral line. The irrigation water treatments were 20,30 and 40 min. every 3 days $(800,1200$ and 1600 $\mathrm{m}^{3} /$ fed).

\section{Bio-fertilizers:}

- Algae extract (Spirulina platensis) was used as foliar spray twice per season after 15 days from planting and 15 days from the cut at a concentration of 1.5-litre extract/200-litre water/feddan.

- A mixture of microorganisms (Azotobacter chroococcum as nitrogen-fixing bacteria, Bacillus megatherium var. phosphaticum as phosphate solubilizing bacteria, and $B$. circulanse as potassium solvent) was used as a source of biofertilizer on rosemary plants. 


\section{K.A. Hammam et al.}

- Microorganisms were obtained from Central Lab. of Organic Agric., A.R.C., while Arbuscular mycorrhizal fungi (AMF) and the blue-green algae (Spirulina platensis) extract was obtained from National Research Center, Egypt.

- Physical and chemical analysis of the experimental soil was done at Soils; Water and Environment Research Institute Laboratories (ARC) are shown in Table (1). according to the methods of Sparks (1996).

\section{Data recorded:}

\section{Vegetative growth:}

Plant height $(\mathrm{cm})$, number of branches/plant, herb fresh and dry weights (g)/plant. The growth parameters were measured at the first cut and repeated again at the second one.

\section{Essential oil determination:}

The volatile oil percentages in rosemary obtained from each replicate of every treatment were determined by a water distillation method described in British Pharmacopeia (2002), using the following equation: Volatile oil percentage $=$ oil volume in the graduated tube/fresh weight of sample $\times 100$, then the oil yield/plant was calculated.

Essential oil composition: The obtained essential oil from the second cut of the second season was analyzed using GC according to the methods described by Meshkatalsadata et al. (2012) in the Laboratory of Medicinal and Aromatic Plants Research Department, Horticulture Research Institutes.

\section{Chemical constituents:}

Leaf samples were air dried at $70{ }^{\circ} \mathrm{C}$ for $24 \mathrm{~h}$, then ground to a fine powder and was taken for determination of the following chemical constituents: - Total nitrogen was determined by micro-Kjeldahle method according to Allen et al. (1974). Determination of phosphorus in dry leaves using Atomic Absorption Spectrophotometer as described by Cottenie et al. (1982) and potassium was determined by flame photometer as described by A.O.A.C. (1995).

Table 1. Physical and chemical properties of the experimental soil in the two seasons.

\begin{tabular}{|c|c|c|c|}
\hline & Parameter & First season & Second season \\
\hline \multirow{5}{*}{ Physical analysis } & Fine sand (\%) & 75.20 & 72.00 \\
\hline & Coarse sand (\%) & 13.22 & 14.40 \\
\hline & Silt (\%) & 6.28 & 7.50 \\
\hline & Clay $(\%)$ & 5.30 & 6.10 \\
\hline & Soil texture & Sandy soil & Sandy soil \\
\hline \multirow{13}{*}{ Chemical analysis } & Organic matter $\left(\mathrm{g} \mathrm{kg}^{-1}\right)$ & 0.25 & 0.22 \\
\hline & $E C\left(\mathrm{dSm}^{-1}\right)$ & 1.68 & 1.74 \\
\hline & pH & 7.50 & 7.90 \\
\hline & & Cations (meq $\mathrm{I}^{-1}$ ) & \\
\hline & $\mathbf{C a}^{++}$ & 3.18 & 3.31 \\
\hline & $\mathbf{M g}^{++}$ & 3.61 & 4.10 \\
\hline & $\mathrm{Na}^{+}$ & 7.12 & 7.33 \\
\hline & $\mathbf{K}^{+}$ & 1.55 & 1.47 \\
\hline & & Anions (meq $\left.\mathrm{l}^{-1}\right)$ & \\
\hline & $\mathrm{HCO}_{3}^{-}$ & 2.31 & 2.40 \\
\hline & $\mathrm{Cl}^{-}$ & 7.41 & 6.91 \\
\hline & $\mathrm{SO}_{4}^{--}$ & 8.02 & 7.11 \\
\hline & Adj. SAR. $=$ Sodium absorption ratio & 8.11 & 7.27 \\
\hline
\end{tabular}


Proline content (ppm) was analyzed as described by Bates et al. (1973).

Data recorded were statistically analyzed, by using computer package program of MSTAT-C. Mean separation was done using least significant difference (LSD) at 5\% level of significance as described by Gomez and Gomez (1984).

\section{RESULTS AND DISCUSSION}

\section{Plant vegetative growth characteristics:}

\section{Plant height:}

Data presented in Table (2) indicated that irrigation affected plant height of rosemary in both seasons. Furthermore, the most favorable treatment was $1200 \mathrm{~m}^{3} / \mathrm{fed}$ giving values of 36.49 and $34.18 \mathrm{~cm}$ in the first season and 37.86 and 35.38 in the second season for the first and second cuts, respectively). In this concern, Mirzaie et al. (2020) on lemongrass (Cymbopogon citratus) plant growth significantly was reduced by water stress, but it was improved by PGPR application.
Data show also positive response in rosemary growth in term of plant height due to bio-fertilizers. Moreover, in the first season, PGPR treatment significantly increased plant height comparing with control (36.91 and $34.86 \mathrm{~cm}$ in the first and second cuts, respectively). A similar trend was found in the second season as the highest plants $(38.27$ and $36.30 \mathrm{~cm}$ in the first and second cuts, respectively) were produced due to using PGPR. In this respect, Parisa Sharifi (2017) on hyssop (Hyssopus officinalis) indicated that growth-promoting bacteria is by producing some metabolites as growth regulators, or types of vitamins as well as improved access to nutrients directly increase plant growth and development.

Regarding the interaction between irrigation and bio-fertilizers effect on plant height of rosemary, data presented in Table (2) indicated that, in the two cuts of both seasons, control plants gave the shortest plants. On the other hand, the tallest plants were those supplied with irrigation rate of $1200 \mathrm{~m}^{3} /$ fed combined with PGPR giving values of $38.73,36.69$ and $40.01,38.05 \mathrm{~cm}$ in the first and second cuts of the first and

Table 2. Effect of different irrigation rates and bio-fertilizers and their interactions on plant height $(\mathrm{cm})$ of rosemary for two cuts in both seasons.

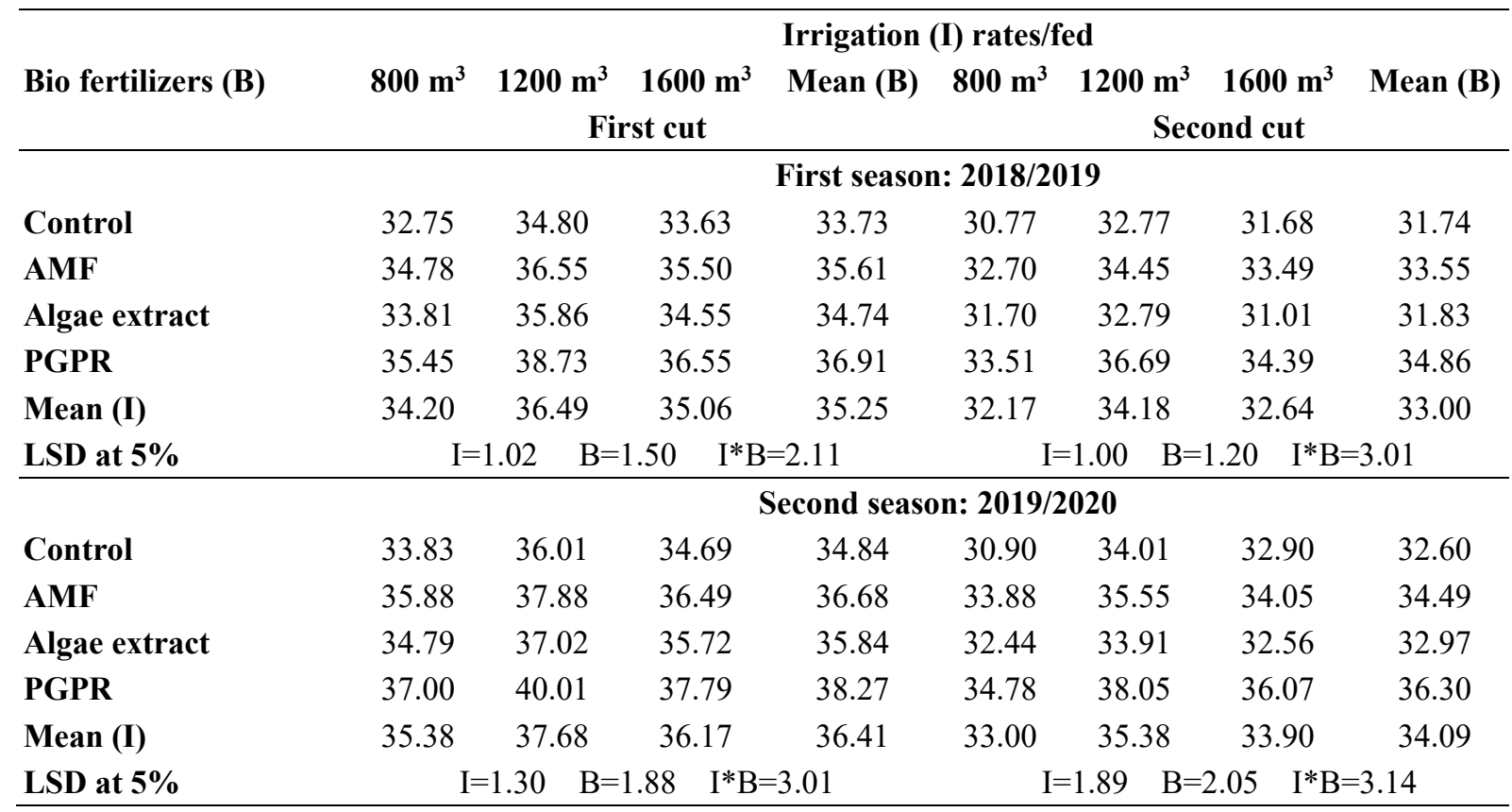




\section{K.A. Hammam et al.}

second seasons, respectively, followed by plants which received irrigation rate of $1200 \mathrm{~m}^{3} /$ fed combined with AMF. The recorded values were generally decreased by decreasing the application rates of irrigation to $1600 \mathrm{~m}^{3} / \mathrm{fed}$. The favorable effect of PGPR on the plant height of rosemary plant is similar to that recorded by Zahir et al. (2004) and Nadeem et al. (2014).

\section{Number of branches/plant:}

Data listed in Table (3) show a positive effect on number of branches per plant of rosemary due to irrigation and bio-fertilizers and their interactions over the two cuts of two seasons.

Significant increases were recorded in general, with irrigation treatments during the two cuts of the two seasons. Furthermore, the irrigation rate of $1200 \mathrm{~m}^{3} / \mathrm{fed}$ recorded the highest increases in rosemary branches number (with mean of 8.29 and 11.93 for the first season, 8.68 and 12.12 for the second one, in the first and second cuts, respectively).

As for bio-fertilizers effect, it was clear that bio-fertilizers application recorded an increment in number of branches/plant during the two cuts of the two seasons compared to control plants. The highest values were recorded in the plants treated with PGPR (8.83 and 12.75 for the first season, and 9.35 and 12.72 for the second season, in the first and second cuts, respectively).

In the concern of irrigation and biofertilizers interaction, data presented in Table (3) reflected that treatments of irrigation at the rate of $1200 \mathrm{~m}^{3} / \mathrm{fed}$ combined with PGPR produced the highest number of branches/plant during the two cuts of both seasons with values of 9.88 and 13.47 for the first season, and 10.34 and 13.39 for the second one, in the first and second cuts, respectively).

In medicinal and aromatic plants, experiments with PGPR indicated that growth and oil yield increase in Italian oregano and Origanum majorana L. (Banchio et al., 2008 and 2010), rosemary (Leithy et al., 2006), Pelargonium graveolens (Mishra et al., 2010), common basil (Ordookhani et al., 2011), Mexican marigold (Cappellari et al., 2013), Thymus daenensis (Bahadori et al., 2013).

Table 3. Effect of different irrigation rates and bio-fertilizers and their interactions on number of branches/plant of rosemary for two cuts in both seasons.

\begin{tabular}{|c|c|c|c|c|c|c|c|c|}
\hline \multirow{3}{*}{ Bio fertilizers (B) } & \multicolumn{8}{|c|}{ Irrigation (I) rates/fed } \\
\hline & $800 \mathrm{~m}^{3}$ & $1200 \mathrm{~m}^{3}$ & $1600 \mathrm{~m}^{3}$ & Mean (B) & $800 \mathrm{~m}^{3}$ & $1200 \mathrm{~m}^{3}$ & $1600 \mathrm{~m}^{3}$ & Mean (B) \\
\hline & \multicolumn{4}{|c|}{ First cut } & \multicolumn{4}{|c|}{ Second cut } \\
\hline & \multicolumn{8}{|c|}{ First season: $2018 / 2019$} \\
\hline Control & 6.11 & 7.56 & 6.44 & 6.70 & 9.24 & 10.61 & 8.55 & 9.47 \\
\hline AMF & 7.57 & 8.11 & 7.89 & 7.86 & 10.47 & 11.51 & 9.34 & 10.44 \\
\hline Algae extract & 7.01 & 7.59 & 7.15 & 7.25 & 10.44 & 12.11 & 10.90 & 11.15 \\
\hline PGPR & 8.11 & 9.88 & 8.51 & 8.83 & 12.78 & 13.47 & 12.01 & 12.75 \\
\hline Mean (I) & 7.20 & 8.29 & 7.50 & 7.66 & 10.73 & 11.93 & 10.20 & 10.95 \\
\hline \multirow[t]{2}{*}{ LSD at $5 \%$} & \multicolumn{3}{|c|}{$I=0.65$} & 2.11 & & $=1.02 \mathrm{~B}=$ & $2.01 \quad \mathrm{I} * \mathrm{~B}$ & $=3.00$ \\
\hline & \multicolumn{8}{|c|}{$2019 / 2020$} \\
\hline Control & 6.44 & 7.58 & 6.77 & 6.93 & 9.55 & 10.59 & 8.55 & 9.56 \\
\hline AMF & 7.80 & 8.55 & 8.00 & 8.12 & 10.80 & 11.74 & 9.46 & 10.67 \\
\hline Algae extract & 7.45 & 8.23 & 7.78 & 7.82 & 10.57 & 12.77 & 11.01 & 11.45 \\
\hline PGPR & 8.67 & 10.34 & 9.04 & 9.35 & 12.54 & 13.39 & 12.22 & 12.72 \\
\hline Mean (I) & 7.59 & 8.68 & 7.90 & 8.05 & 10.87 & 12.12 & 10.31 & 11.10 \\
\hline LSD at $5 \%$ & \multicolumn{2}{|c|}{$\mathrm{I}=0.70 \quad \mathrm{~B}$} & $1.33 \mathrm{I} * \mathrm{~B}$ & $=2.02$ & \multicolumn{2}{|c|}{$\mathrm{I}=0.51 \quad \mathrm{~B}$} & \multicolumn{2}{|c|}{$4 \quad I^{*} B=2.00$} \\
\hline
\end{tabular}




\section{Fresh and dry weights/plant:}

Data presented in Tables (4 and 5) indicated that in the first season, fresh and dry weights/plant were affected increased by irrigation rates. Moreover, the rate of 1200 $\mathrm{m}^{3} /$ fed was the most effective irrigation treatment in this aspect (68.33 and 108.34 $\mathrm{g} /$ plant for the fresh weight, 22.99 and 36.00 $\mathrm{g} /$ plant for the dry weight in the first and second cuts, respectively).

The results recorded in the second season (Tables, 4 and 5) confirmed those obtained in the first one. Irrigation at the rate of $1200 \mathrm{~m}^{3} /$ fed gave the heaviest fresh and dry weights/ plant $(59.42$ and $99.07 \mathrm{~g} /$ plant for the fresh weight, 20.43 and $34.54 \mathrm{~g} /$ plant for the dry weight in the first and second cuts, respectively).

Regarding the effect of bio-fertilizers on the fresh and dry weights/plant, data in Tables (4 and 5) show that plants receiving no bio-fertilizers gave the lowest values of fresh and dry weights/plant in the two cuts of both seasons. On the other hand, in the two cuts of the first season, PGPR was the most effective treatment which significantly increased fresh and dry weights per plant over all other treatments giving values of
64.71 and $105.92 \mathrm{~g} / \mathrm{plant}$ for the fresh weight, 22.60 and $36.33 \mathrm{~g} /$ plant for the dry weight in the first and second cuts, respectively.

In the second season, the same trend was detected. Accordingly, PGPR was the most effective treatment giving 66.46 and 103.98 $\mathrm{g} /$ plant for the fresh weight, 23.85 and 37.67 $\mathrm{g} /$ plant for the dry weight in the first and second cuts, respectively. The favorable effect of PGPR on the herb fresh of rosemary plants is similar to that recorded by Kutlu et al. (2019) on Turkish oregano (Origanum onites L.)

Concerning the interaction between irrigation rate and biofertilizer, results presented in Tables (4 and 5) show that in both seasons, a significant interaction was detected between irrigation rates of 1200 $\mathrm{m}^{3} /$ fed and PGPR treatment on fresh and dry weights/ plant (74.98, 115.28, 77.09 and $116.05 \mathrm{~g} /$ plant for the fresh weight and 26.78, 41.12, 28.09 and 43.28 for the dry weight in the first and second cuts of first and second seasons, respectively) followed by the treatment of $1200 \mathrm{~m}^{3} /$ fed with AMF. Bio-fertilizers favorable effect on rosemary plants is in harmony with that presented by

Table 4. Effect of different irrigation rates and bio-fertilizers and their interactions on herb fresh weight /plant (g) of rosemary for two cuts in both seasons.

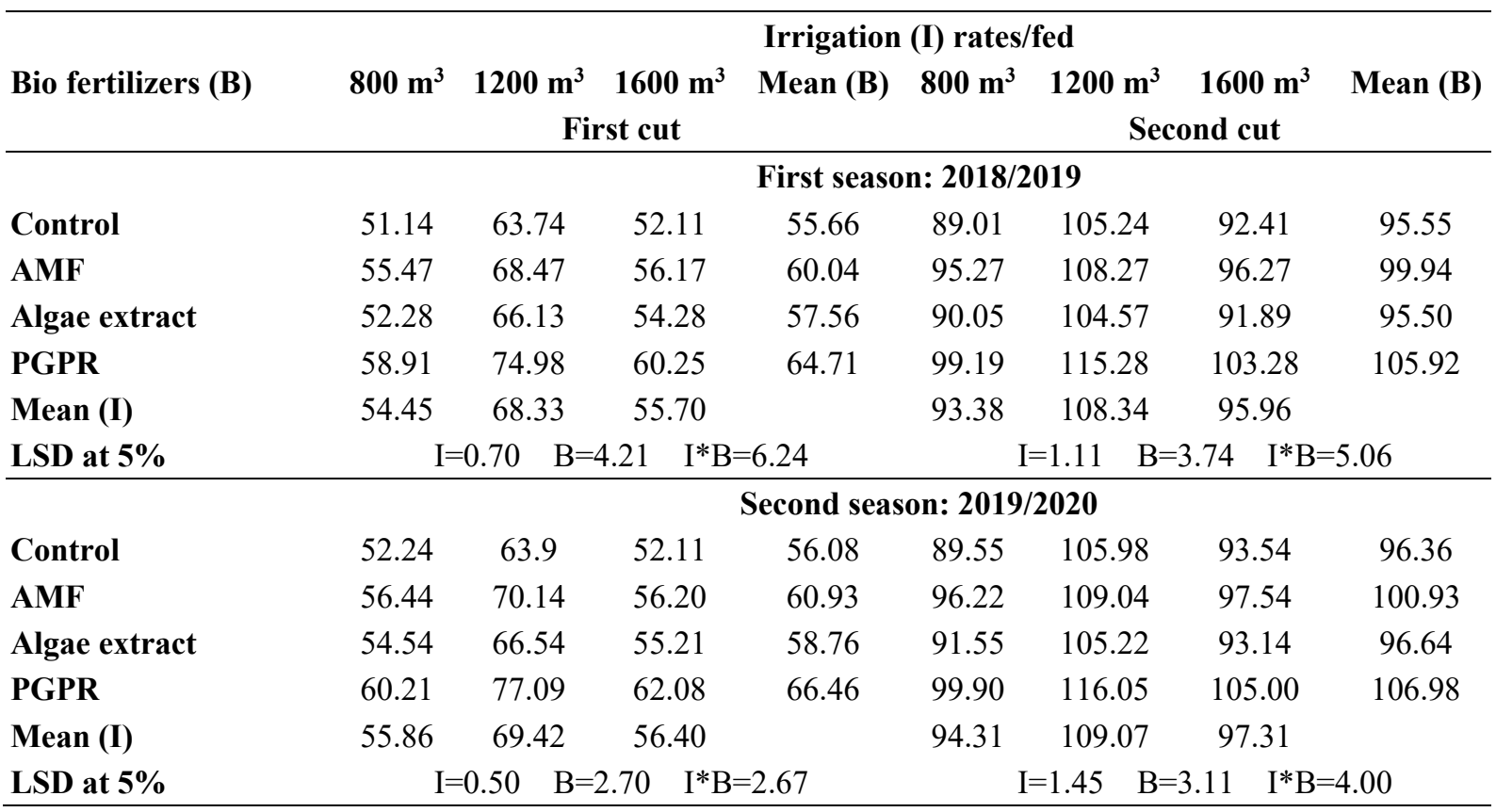


K.A. Hammam et al.

Table 5. Effect of different irrigation rates and bio-fertilizers and their interactions on herb dry weight /plant (g) of rosemary for two cuts in both seasons.

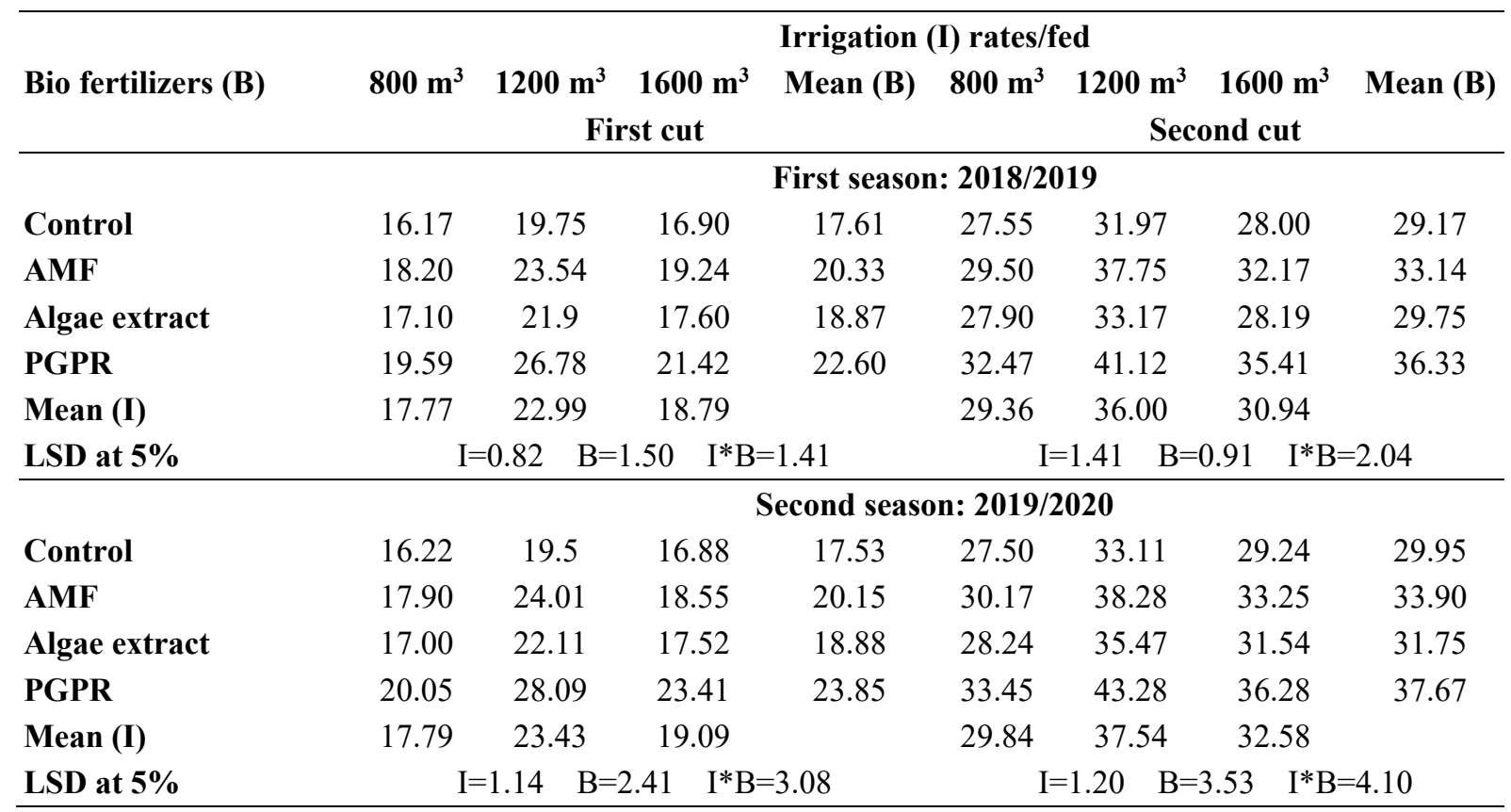

Abeer et al. (2019). PGPR improved the growth and yield of rosemary, particularly in moderate and severe stress conditions. Similarly, the improvement of plant height and biomass with PGPR application were reported on lemongrass (Mirzaie et al., 2020).

\section{Essential oil determinations:}

Results presented in Table (6) revealed that in the first and second seasons, the application of irrigation rates significantly affected the oil percentage. However, the irrigated plants at $800 \mathrm{~m}^{3}$ gave the highest mean value of oil percentage $(0.28,0.3,0.28$ and $0.30 \%$ in the first and second cuts of the first and second seasons, respectively) comparing with the other two rates. Those results are in harmony with those reported by Hassan et al. (2013) on rosemary plant. He revealed that the volatile oil percentage was increased under deficit irrigation.

Regarding the effect of irrigation rate on essential oil yield/plant, data presented in Table (7) show that oil yield $\mathrm{ml} /$ plant was significantly affected by irrigation rate. Irrigation at the rate of $\left(1200 \mathrm{~m}^{3} / \mathrm{fed}\right.$ gave the highest mean of oil yield/plant $(0.17$ and
$0.33 \mathrm{ml} /$ plant in the first and second cuts of the first season, and 0.18 and $0.30 \mathrm{ml} / \mathrm{plant}$ in the first and second cuts of the second season, respectively). These results are in agreement with those reported by Sarmoum et al. (2019) who reported that non irrigated rosemary plants showed the highest essential oil yield.

For essential oil percentage as affected by bio-fertilizers inoculation, data presented in Tables (6) show that bio-fertilizers, generally, had a favorable effect on the resulted oil percentage comparing to untreated control during the two seasons. Furthermore, plants treated with PGPR had a significantly higher mean of oil percentage $(0.28,0.33,0.29$ and $0.32 \%$ in the first and second cuts of the first and second seasons, respectively), comparing with untreated plants (control).

Regarding the oil yield/ plant, data listed in Table (7) revealed that plants which received PGPR was the superior treatment, which gave the highest significant mean values represented essential oil yield per plant with values of 0.18 and $0.35 \mathrm{ml}$, in the first and second cuts, respectively in the first season and 0.20 and $0.34 \mathrm{ml} / \mathrm{plant}$, in the 
Table 6. Effect of different irrigation rates and bio-fertilizers and their interactions on essential oil percentage based on fresh herb of rosemary for two cuts in both seasons.

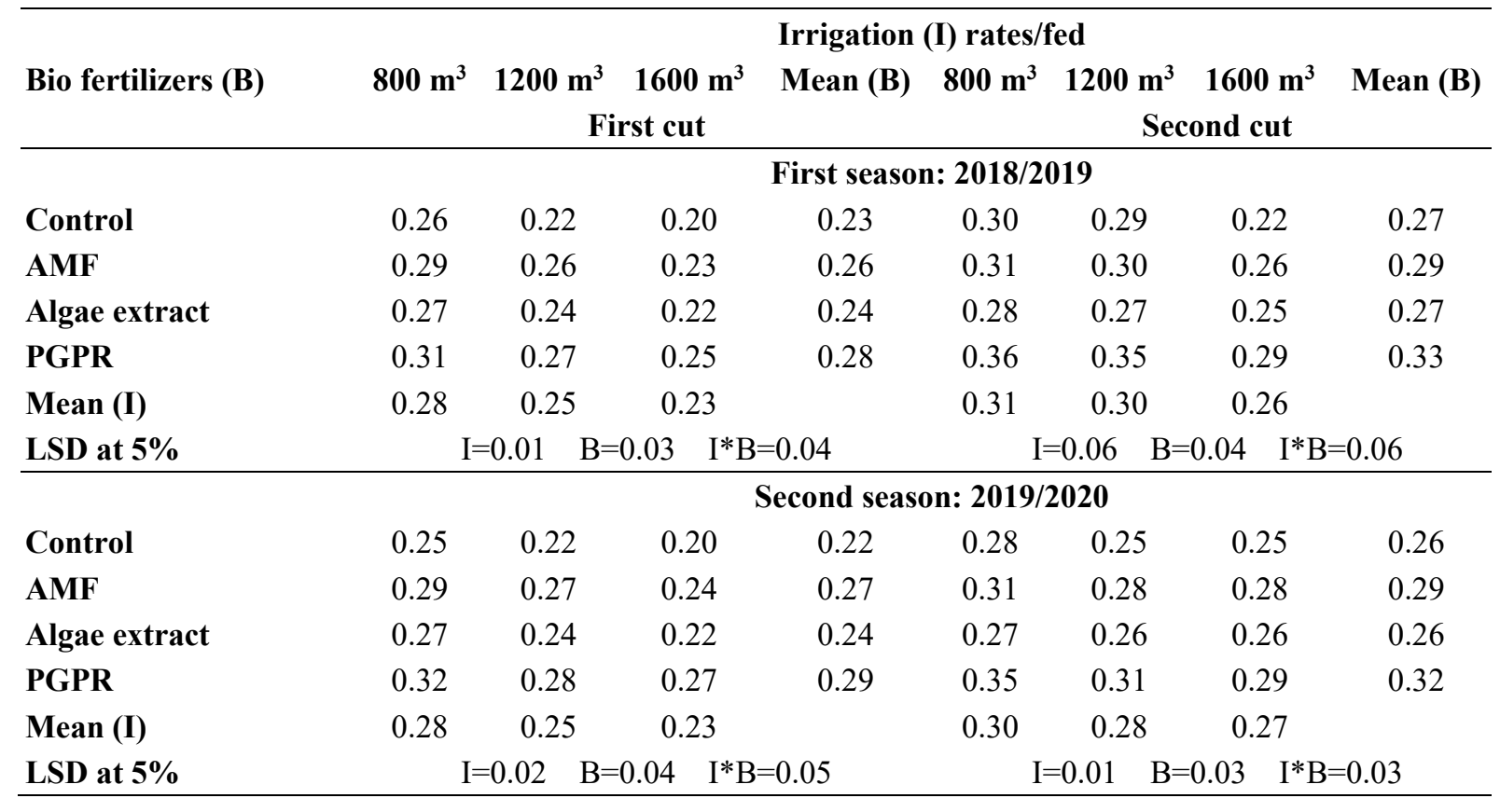

Table 7. Effect of different irrigation rates and bio-fertilizers and their interactions on essential yield/plant $(\mathrm{ml})$ of rosemary for two cuts in both seasons.

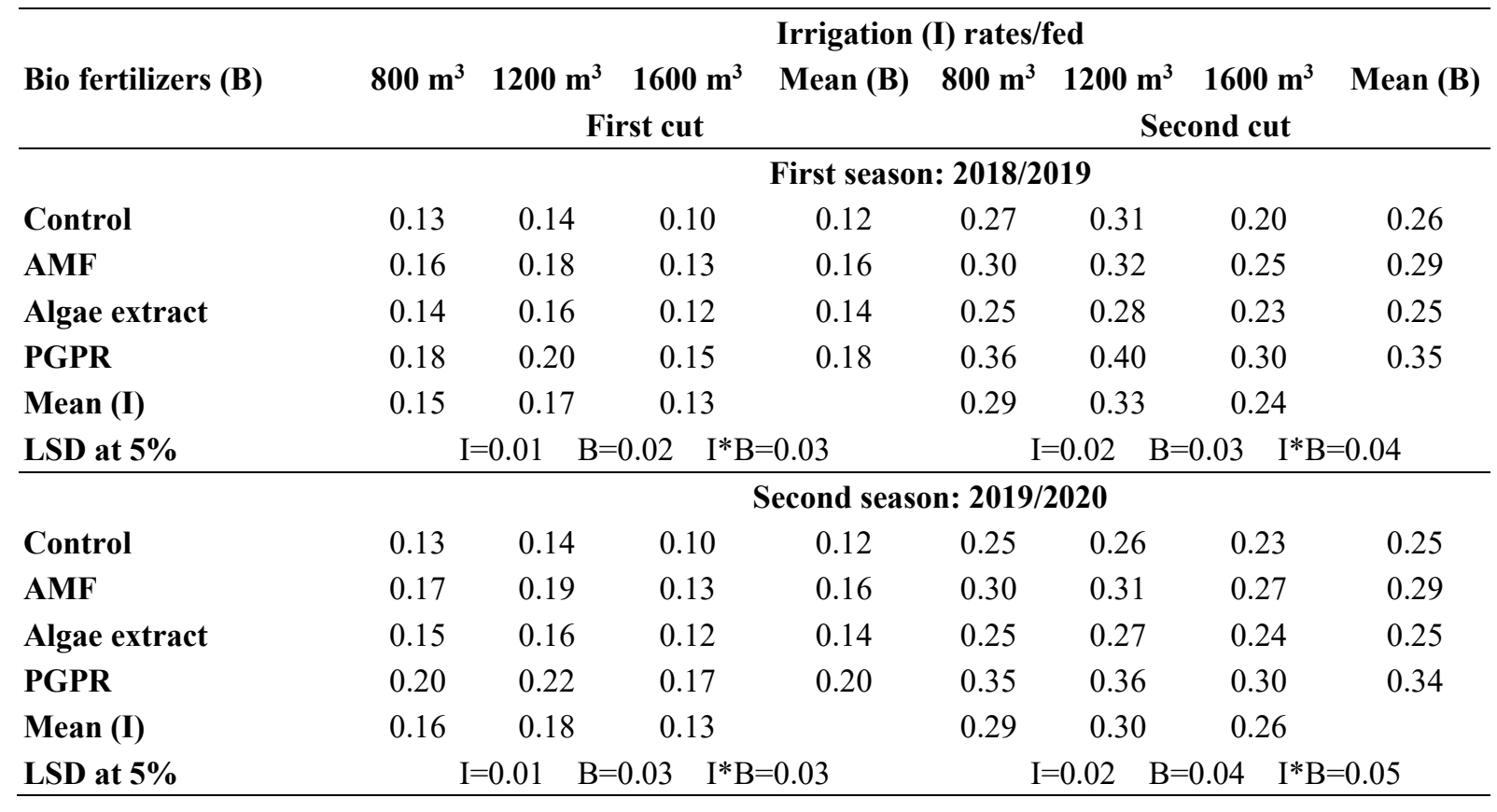

first and second cuts of the second season, respectively compared with control plants. These results are in agreement with these of Abeer et.al (2019) on rosemary who stated that mixed treatment of $(\mathrm{AMF}+\mathrm{BM}+\mathrm{AZB})$ gave the maximum values in volatile oil yield/ plant.

As for the interaction between irrigation rate and biofertilizer treatments, data presented in Table (6) reflected that in the both seasons, the highest oil percentage $(0.31$ 


\section{K.A. Hammam et al.}

and $0.36 \%$ for the first season, 0.32 and $0.35 \%$ for the second one in the first and second cuts, respectively) were produced from plants which received $800 \mathrm{~m}^{3} /$ fed with PGPR followed by those supplemented with $800 \mathrm{~m}^{3} / \mathrm{fed}$ with AMF. On the other hand, plants receiving no bio-fertilizers and 1600 $\mathrm{m}^{3}$ irrigation treatments gave the lowest values of oil percentage $(0.20$ and $0.22 \%$ for the first season, 0.20 and $0.25 \%$ for the second one in the first and second cuts, respectively).

As for essential oil yield/ plant, it is evident that the interaction between irrigation rates and biofertilizer affected essential oil yield/plant in fresh herb of rosemary plant during the two seasons (Table, 7). Furthermore, plants which received $1200 \mathrm{~m}^{3} /$ fed irrigation combined with PGPR had the highest essential oil yield/plant comparing to all other interaction treatments during two seasons, these values were 0.20 and $0.40 \mathrm{ml}$ in the first season and 0.22 and $0.36 \mathrm{ml}$ in the second season for the first and second cuts, respectively. On the other hand, the lowest values $(0.10$ and 0.20 $\mathrm{ml}$ in the first and second cuts and 0.10 and $0.23 \mathrm{ml}$ in the first and second cuts of the first and second seasons, respectively) were recorded in the plants treated with $1600 \mathrm{~m}^{3}$ irrigation without bio-fertilizers.

\section{Essential oil Components:}

Main components of essential oil $(\alpha-$ pinene, camphene, limonene, 1,8 cineole, linalool, camphor, borneol, bornyl acetate, and $\beta$ - caryophyllene) from rosemary plants are shown in Table (8).

Irrigation treatment with $800 \mathrm{~m}^{3} / \mathrm{fed}$ resulted in the highest mean value of 1,8 cineole $(8.05 \%)$, camphor $(11.31 \%)$, borneol (7.80\%), bornyl acetate $(6.20 \%)$, and $\beta$ caryophyllene $(2.53 \%)$. However, the treatment of $1200 \mathrm{~m}^{3} / \mathrm{fed}$ resulted in the highest values of $\alpha$-pinene, and linalool.

As for bio-fertilizers effect on the essential oil components, (Table, 8) data showed that control treatment gave the highest percentage of total limonene
(7.20\%), whereas, the highest percentage of $\alpha$ - pinene (13.71\%), camphene (6.14\%), 1,8 cineole $(8.72 \%)$, linalool $(6.15 \%)$, bornyl acetate $(6.73 \%)$, and $\beta$-caryophyllene $(2.69 \%)$ were obtained by using PGPR. On the other hand, algae treatment gave the highest percentage of camphor $(12.44 \%)$ and borneol $(8.31 \%)$.

Regarding the interaction between irrigation rates and bio-fertilizers, data listed in Table (8) clearly show that $800 \mathrm{~m}^{3} / \mathrm{fed}$ plus PGPR treatment was superior in that aspect giving the highest percentage of total components $(70.67 \%)$ as camphene $(6.22 \%)$, 1,8 cineole $(9.44 \%)$, linalool $(6.22 \%)$, and bornyl acetate $(7.14 \%)$. However, the highest values of camphor $(8.55 \%)$, borneol $(12.89 \%)$, and $\beta$-caryophyllene $(3.14 \%)$ were recorded in the essential oil extracted from plants treated with $800 \mathrm{~m}^{3} / \mathrm{fed}$ plus algae extract. The highest $\alpha$ - pinene percentage $(13.90 \%)$ was produced from plants treated with $1600 \mathrm{~m}^{3} /$ fed plus PGPR. limonene $(7.55 \%)$ was produced from the treatment of $1200 \mathrm{~m}^{3} /$ fed alone.

\section{Nitrogen, phosphorus and potassium \%:}

Respecting the nutritional status of rosemary plant as influenced by three irrigation treatments in the second season are shown in Table (9), the N, P and $\mathrm{K} \%$ in dried herb recorded higher values with medium irrigation, i.e., at rate of $1200 \mathrm{~m}^{3}$ in both cuts. This finding could be attributed to the fact that when soil moisture decreased, the mobility of nutrient in the soil is lowered and the rate of nutrients flows to root absorption zone decreased. Moreover, the statistical calculation of the collected data reveals that the values of the above constituents significantly varied within the irrigation treatments. The results obtained by Shalapy and Eisa (2016) support the results obtained in this investigation which found that content of $\mathrm{N}, \mathrm{P}$ and $\mathrm{K}$ in dried herb of basil plant recorded its higher values with medium irrigation.

Data concerning rosemary herb nitrogen, phosphorus and potassium presented in 
Scientific J. Flowers \& Ornamental Plants, 8(1):135-151 (2021)

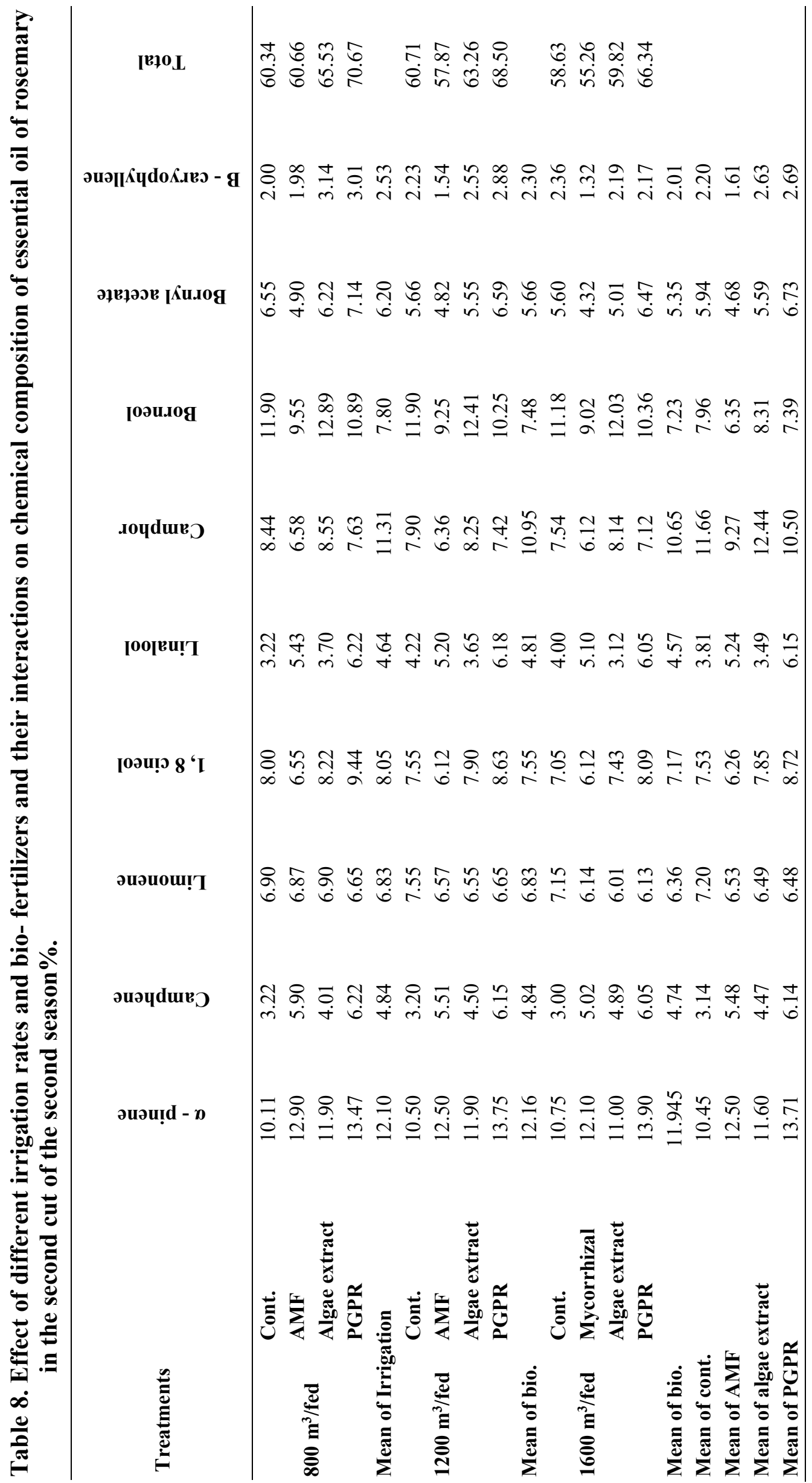


Table 9. Effect of different irrigation rates and bio-fertilizers and their interactions on essential yield/plant $(\mathrm{ml})$ of rosemary herb in the second season.

\begin{tabular}{|c|c|c|c|c|c|c|c|c|}
\hline \multirow{3}{*}{ Bio fertilizers (B) } & \multicolumn{8}{|c|}{ Irrigation (I) rates/fed } \\
\hline & $800 \mathrm{~m}^{3}$ & $1200 \mathrm{~m}^{3} \quad 1$ & $1600 \mathrm{~m}^{3}$ & Mean (B) & $800 \mathrm{~m}^{3}$ & $1200 \mathrm{~m}^{3}$ & $1600 \mathrm{~m}^{3}$ & Mean (B) \\
\hline & \multicolumn{4}{|c|}{ First cut } & \multicolumn{4}{|c|}{ Second cut } \\
\hline & \multicolumn{8}{|c|}{ Nitrogen \% } \\
\hline Control & 2.12 & 2.29 & 2.18 & 2.20 & 2.20 & 2.40 & 2.25 & 2.28 \\
\hline AMF & 2.24 & 2.44 & 2.34 & 2.34 & 2.38 & 2.65 & 2.45 & 2.49 \\
\hline Algae extract & 2.19 & 2.35 & 2.27 & 2.27 & 2.29 & 2.52 & 2.36 & 2.39 \\
\hline PGPR & 2.35 & 2.50 & 2.43 & 2.43 & 2.49 & 2.81 & 2.60 & 2.63 \\
\hline Mean (I) & 2.23 & 2.40 & 2.31 & & 2.34 & 2.60 & 2.42 & \\
\hline \multirow[t]{2}{*}{ LSD at $5 \%$} & & $\mathrm{I}=0.03 \mathrm{~B}=0.05$ & $\mathrm{I}^{*} \mathrm{~B}=0.07$ & & & $\mathrm{I}=0.02 \quad \mathrm{~B}=0.0$ & $4 \mathrm{I} * \mathrm{~B}=0.06$ & \\
\hline & \multicolumn{8}{|c|}{ Phosphorus \% } \\
\hline Control & 0.20 & 0.30 & 0.25 & 0.25 & 0.23 & 0.36 & 0.29 & 0.29 \\
\hline AMF & 0.35 & 0.41 & 0.37 & 0.38 & 0.39 & 0.52 & 0.45 & 0.45 \\
\hline Algae extract & 0.28 & 0.35 & 0.31 & 0.31 & 0.34 & 0.40 & 0.39 & 0.38 \\
\hline PGPR & 0.38 & 0.47 & 0.40 & 0.42 & 0.43 & 0.58 & 0.49 & 0.50 \\
\hline Mean (I) & 0.30 & 0.38 & 0.33 & & 0.35 & 0.47 & 0.41 & \\
\hline \multirow[t]{2}{*}{ LSD at $5 \%$} & & $\mathrm{I}=0.02 \mathrm{~B}=0.03$ & $3 \mathrm{I} * \mathrm{~B}=0.4$ & & & $\mathrm{I}=0.01 \quad \mathrm{~B}=0.0$ & $2 \mathrm{I} * \mathrm{~B}=0.03$ & \\
\hline & \multicolumn{8}{|c|}{ Potassium \% } \\
\hline Control & 3.20 & 3.35 & 3.25 & 3.27 & 3.26 & 3.51 & 3.32 & 3.36 \\
\hline AMF & 3.40 & 3.53 & 3.47 & 3.47 & 3.51 & 3.64 & 3.53 & 3.56 \\
\hline Algae extract & 3.37 & 3.49 & 3.40 & 3.42 & 3.44 & 3.54 & 3.47 & 3.48 \\
\hline PGPR & 3.50 & 3.65 & 3.52 & 3.56 & 3.58 & 3.70 & 3.63 & 3.64 \\
\hline Mean (I) & 3.37 & 3.51 & 3.41 & & 3.45 & 3.60 & 3.49 & \\
\hline LSD at $5 \%$ & & $\mathrm{I}=0.01 \quad \mathrm{~B}=0.03$ & $I^{*} B=0.03$ & & & $\mathrm{I}=0.01 \quad \mathrm{~B}=0.0$ & $2 \mathrm{I} * \mathrm{~B}=0.02$ & \\
\hline
\end{tabular}

Table (9) deduce that treated rosemary plants with different sources of biofertilization affected the nitrogen, phosphorus and potassium $\%$ in the herb. The highest $\mathrm{N}, \mathrm{P}$ and $\mathrm{K} \%$ were obtained with the treatment of PGPR, meanwhile, the lowest \% happened with the untreated plants in the two cuts. These results agreed with those obtained by Al-Fraihat et al. (2011). They indicated that bio-fertilizers stimulated N, P and K contents in herb tissues of marjoram plants.

The effect of the interaction between irrigation treatment and bio-fertilizers on chemical contents of the rosemary plant, i.e.; $\mathrm{N}, \mathrm{P}$ and $\mathrm{K} \%$ in the herb are presented in Table (9), in the present investigation, application of PGPR under irrigation rate of $1200 \mathrm{~m}^{3}$ gave the highest effect on N, P and $\mathrm{K} \%$ in rosemary plant in the $1^{\text {st }}$ and $2^{\text {nd }}$ cuts as well, using of biological fertilizer improved nutrient uptake and growth of rosemary under water stress. Our results suggest that the application of inoculation with AMF and PGPR could improve the defense against drought stress with overall produces positive outcomes of plant production mainly owing to the several nutrition-related benefits that this class of soil beneficial microbes can provide to their host-plants (Anli et al., 2020).

\section{Proline content:}

The results presented in Table (10) show that there was a steady significant increase in proline content due to decreasing the irrigation rate. Moreover, the lowest irrigation rate $\left(800 \mathrm{~m}^{3} / \mathrm{fed}\right)$ gave the highest value of proline content (3.71 and 3.89 $\mathrm{mg} / 100 \mathrm{~g}$ in the first and second cuts, respectively). 
Table 10. Effect of different irrigation rates and bio-fertilizers and their interactions on proline content $(\mathrm{mg} / 100 \mathrm{~g})$ of rosemary plant in the second season for two cuts.

\begin{tabular}{|c|c|c|c|c|c|c|c|c|}
\hline \multirow{3}{*}{ Bio fertilizers (B) } & \multicolumn{8}{|c|}{ Irrigation (I) rates/fed } \\
\hline & $800 \mathrm{~m}^{3}$ & $1200 \mathrm{~m}^{3}$ & $1600 \mathrm{~m}^{3}$ & Mean (B) & $800 \mathrm{~m}^{3}$ & $1200 \mathrm{~m}^{3}$ & $1600 \mathrm{~m}^{3}$ & Mean (B) \\
\hline & \multicolumn{4}{|c|}{ First cut } & \multicolumn{4}{|c|}{ Second cut } \\
\hline Control & 4.22 & 3.90 & 3.90 & 4.01 & 4.50 & 4.02 & 4.00 & 4.17 \\
\hline AMF & 4.00 & 3.71 & 3.50 & 3.74 & 4.14 & 3.94 & 3.62 & 3.90 \\
\hline Algae extract & 3.50 & 3.21 & 3.00 & 3.24 & 3.65 & 3.55 & 3.16 & 3.45 \\
\hline PGPR & 3.10 & 2.95 & 2.50 & 2.85 & 3.25 & 3.19 & 2.88 & 3.11 \\
\hline Mean (I) & 3.71 & 3.44 & 3.23 & & 3.89 & 3.68 & 3.42 & \\
\hline LSD at $5 \%$ & & $99 \quad \mathrm{~B}=0$. & $2 \quad \mathrm{I} * \mathrm{~B}=0$ & & & $0.11 \mathrm{~B}=0$ & $7 \quad I * B=0$ & \\
\hline
\end{tabular}

As for the effect of bio-fertilizers, data also showed that PGPR was the most effective treatment as it significantly decreased proline content of rosemary plants giving 2.85 and $3.11 \mathrm{mg} / 100 \mathrm{~g}$ in the first and second cuts, respectively comparing with control which gave the highest values (4.01 and $4.17 \mathrm{mg} / 100 \mathrm{~g}$ in the first and second cuts, respectively)

Data presented in Table (10) revealed also that proline content in rosemary plant significantly affected by the interaction between irrigation rates and bio-fertilizers. The highest values (4.22 and $4.50 \mathrm{mg} / 100 \mathrm{~g}$ in the first and second cuts, respectively) were recorded for the treatment of 800 $\mathrm{m}^{3} /$ fed alone. However, the treatment of $1600 \mathrm{~m}^{3} /$ fed plus PGPR gave the lowest proline content $(2.50$ and $2.88 \mathrm{mg} / 100 \mathrm{~g}$ in the first and second cuts, respectively).

Plant growth-promoting rhizobacteria (PGPR) play a role in alleviating drought stress in plants through some known mechanisms include: (1) increasing plant root system and nutrient and water uptake and the generation of phytohormones (e.g., ABA (abscisic acid), GA (gibberellic acid), auxin, i.e., indole-3-acetic acid (IAA), and CK (cytokinins); (2) synthesizing of enzyme ACC deaminase, an enzyme involved in decreasing the level of stress-induced ethylene in the root of developing plants and improvement of non-biological stresses resistance (Glick, 2014); (3) Increasing the availability and solubilization and mineralization of nutrients, particularly mineral phosphate, and providing N2 for the plant through biological nitrogen fixation; (4) osmolyte accumulation in plants through the overproduction of organic compounds such as proline, glycine betaine, etc. and increasing total sugar content; (5) inducing plant synthesis of antioxidant enzymes (Etesami and Maheshwari, 2018).

\section{CONCLUSION}

The results showed that water stress $(800$ $\mathrm{m}^{3} /$ fed,) significantly reduced growth characteristics (plant height, number of branches/plant, herb fresh and dry weights/plant) and the highest oil percentage/herb of rosemary plants. In addition, the use of biological fertilizer improved nutrient uptake and growth of rosemary under water stress. Application of PGPR, AMF and Algae had considerably positive effects on all stages of plant growth and improved the plant height, number of branches/plant, herb fresh and dry weights/plant, oil percentage and oil yield / plant. Use of PGPR treatment simultaneously decreased the negative effects of drought more than AMF and Algae in all water regimes.

\section{REFERENCES}

Abd El-Wahab, M.A.; Ellabban, H.M. and Moghith, W.M.A. (2016). Combined effect of organic and bio-fertilizers on herb yield and essential oil production of Origanum vulgare L. plants under sandy 


\section{K.A. Hammam et al.}

soil condition. J. Agric. Res. Kafr ElSheikh Univ., 42(2):144-159.

Al-Fraihat, A.H; Al-Dalain S.Y.A.; AlRawashdeh Z.B; Abu-Darwish M.S; and Al-Tabbal J.A. (2011). Effect of organic and bio-fertilizers on growth, herb yield and volatile oil of marjoram plant grown in Ajloun region, Jordan. Journal Medicinal Plants Research, 5(13):28222833.

Allen, S.E.; Grimshaw, H.M.; Parkinsam, J.A. and Quimby, C. (1974). Chemical Analysis of Ecological Materials. Blackwell Scientific publications, Oxford, UK. 565 p.

Al-Sereitia, M.R.; Abu-Amerb, K.M.; Sena, P. (1999). Pharmacology of rosemary (Rosmarinus officinalis L.) and its therapeutic potentials. Indian Journal of Exper-imental Biology, 37:124-131.

Anli, M.; Baslam, M.; Tahiri, A.; Raklami, A.; Symanczik, S.; Boutasknit, A.; AitEl-Mokhtar, M.; Ben-Laouane, R.; Toubali, S.; Rahou, Y.; Chitt, M.; Oufdou, K.; Mitsui, T.; Hafidi, M. and Meddich, A. (2020). Bio-fertilizers as Strategies to Improve Photosynth1etic Apparatus, Growth, and Drought Stress Tolerance in the Date Palm. Front. Plant Sci., 11:1-21. https://doi.org/10.3389 /fpls.2020.516818

AOAC (1995). Official Methods of Analysis. $16^{\text {th }}$ Ed. Association of Official Analytical Chemists, Inc., Virginia, USA., pp 1080-1344.

Bahadori, F.; Ashorabadi, E.S.; Mirza, M.; Matinizade, M. and Abdosi, V. (2013). Improved growth, essential oil yield and quality in Thymus daenensis Celak on mycorrhizal and plant growth promoting rhizobacteria inoculation. International Journal of Agronomy and Plant Production, 4:3384-3391.

Banchio, E.; Bogino, P.C.; Santoro, M.; Torres, L.; Zygadlo, J. and Giordano, W. (2010). Systemic induction of monoterpene biosynthesis in Origanum x majoranum by soil bacteria. Journal of Agricultural and Food Chemistry, 58:650-654.

Banchio, E.; Bogino, P.C.; Zygadlo, J.; Giordano, W. (2008). Plant growth promoting rhizobacteria improve growth and essential oil yield in Origanum majoranum L. Biochemical Systematics and Ecology, 36:766-771.

Bates, L.S.; Waldren, R.P.; and Teare, I.D. (1973). Rapid determination of proline for water stress studies. Plant Soil, 39:205-207.

British Pharmacopoeia. (2002). British Approved Names. A Dictionary of Drug Names for Regulatory Use in the UK. Stationary Office Press, London, UK.

Cappellari, L.D.R.; Santoro, M.V.; Nievas, F.; Giordano, W. and Banchio, E. (2013). Increase of secondary metabolite content in marigold by inoculation with plant growth promoting rhizobacteria. Applied Soil Ecology, 70:16-22.

Cottenie, A.; Verloo, M.; Velghe, M. and Camirlynck, R. (1982). Chemical Analysis of Plant and Soil. Laboratory of Analytical and Agrochemistry. State Univ. Ghent, pp. 271-276.

Ekren, S.; Sonmez, C.; Ozcakal, E.; Kurttas, Y.S.K.; Bayram, E., and Gurgulu, H. (2012). The effect of different irrigation water levels on yield and quality characteristics of purple basil (Ocimum basilicum L.). Agricultural Water Management, 109:155-161.

Etesami, H. and Maheshwari, D.K. (2018). Use of plant growth promoting rhizobacteria (PGPR) with multiple plant growth promoting traits in stress agriculture: Action mechanisms and future prospects. Ecotoxicology and Environmental Safety, 156:225-246.

Glick, B.R. (2014). Bacteria with ACC deaminase can promote plant growth and help to feed the world. Microbiol. Res., 169:30-39. 
Gomez, K.A. and Gomez, A.A. (1984). Statistical Procedures for Agricultural Research, $2^{\text {nd }}$ edition. John Wily and Sons, New York, USA, 680 p.

Hassan, F.A.S.; Bazaid. S. and Ali. E.F. (2013). Effect of deficit irrigation on growth, yield and volatile oil content on Rosmarinus officinalis L. Plant. Journal of Medicinal Plants Studies, 1(3):12-21.

Karimzadeh, A.K.; Ghorbanpour, M.; Marefatzadeh, K. and Hatami M. (2018). Influence of drought stress, bio-fertilizers and zeolite on morphological traits and essential oil constituents in Dracocephalum moldavica L. Journal of Medicinal Plants, 67(17):91-112.

Katalin, P. and Nguyen, H.D. (2019). Benefits of arbuscular mycorrhizal fungi application to crop production under water scarcity. In: Ondrasek, G. (ed.), Drought Detection and Solutions, London, UK. https://doi.org/ 10.5772/intechopen.86595

Kutlu, M.; Cakmakci, R.; Hosseinpour, A. and Karagoz, A.H. (2019). The use of plant growth promoting rhizobacteria (PGPR) effect on essential oil rate, essential oil control, some morphological parameters, and nutrient uptake of Turkish oregano. Applied Ecology and Environmental Research, 17(2):16411653.

Leithy, S.; El-Meseiry, T. and Abdallah, E. (2006). Effect of biofertilizer, cell stabilizer and irrigation regime on rosemary herbage oil yield and quality. Journal of Applied Sciences Research, 2:773-779.

Lopez-Padron, I. (2020). Algae and their uses in agriculture: An update. Cultivos Tropicales, 41(2):1-18.

Mayak S.; Tirosh, T. and Glick, B.R. (2004b). Plant growth-promoting bacteria that confer resistance to water stress in tomato and pepper. Plant Sci., 166:52530.
Meshkatalsadata, M.H.; Salahvarzib, S.; Aminiradpoor, R. and Abdollahi, A. (2012). Identification of essential oil constituents of caraway (Carum carvi) using ultrasonic assist with headspace solid phase micro extraction (UA-HSSPME). Dig. J. Nanomater. Bios., 7(2):637-640.

Miguel, M.G.; Guerrero, C.; Rodrigues, H. and Brito, J. (2007). Essential oils of Rosmarinus officinalis L., effect of harvesting dates, growing media and fertilizers. Proceedings of the $3^{\text {rd }}$ IASME/WSEAS International Conference on Energy, Envi-ronment, Ecosystems and Sustainable Development, Agios Nikolaos, Greece, July, pp. 24-26.

Mirzaie, M.; Ladan M.A.; Hakimi, L. and Danaee, E. (2020). The Plant growth promoting rhizobacteria (PGPR) improve plant growth, antioxidant capacity, and essential oil properties of lemongrass (Cymbopogon citratus) under water stress. Iranian Journal of Plant Physiology, 10(2):3155-3166.

Mishra, R.K.; Prakash, O.; Alam, M. and Dikshit, A. (2010). Influence of plant growth promoting rhizobacteria (PGPR) on the productivity of Pelargonium graveolens L. Herit. Recent Research in Science and Technology, 2(5):53-57.

Nadeem, S.M.; Ahmed, M.; Zahir, Z.A.; Javid, A. and Muhammad, A. (2014). The role of mycorrhizae and plant growth promoting rhizobacteria (PGPR) in improving crop productivity under stressful environments. Journal of Biotechnology Advances, 32:429-448.

Ordookhani, K.; Sharafzadeh, S. and Zare, M. (2011). Influence of PGPR on growth, essential oil and nutrients uptake of sweet basil. Advances in Environmental Biology, 5:672-677.

Parisa, S. (2017). The effect of plant growth promoting rhizobacteria (PGPR), salicylic acid and drought stress on growth indices, the chlorophyll and 


\section{K.A. Hammam et al.}

essential oil of hyssop (Hyssopus officinalis). Biosci., Biotech. Res. Asia, 14(3):1033-1042.

Sadhana, B. (2014). Arbuscular mycorrhizal fungi (AMF) as biofertilizer. Int. J. Curr. Microbiol. App. Sci., 3(4):384-400.

Sandhya, V.; Ali, S.K.Z.; Grover, M.; Reddy, G. and Venkateswarlu, B. (2009). Alleviation of drought stress effects in sunflower seedlings by the exopolysaccharides producing Pseudomonas putida strain GAP-P45. Biol. Fertil. Soils, 46:17-26.

Sarmoum, R.; Haid, S.; Biche, M.; Djazouli, Z.; Zebib, B. and Merah, O. (2019). Effect of salinity and water stress on the essential oil components of rosemary (Rosmarinus officinalis L.). Agronomy, 9(5):214-224.

Shalapy, E.A. and Eisa, E.A. (2016). Effect of irrigation intervals and some different sources of organic fertilizers on growth, volatile oil and chemical composition of Ocimum basillicum L. plant. Egypt J. of Appl. Sci., 31(2):67-93.

Shehata, Abeer M.; Nosir, W.S.E. and Amed, A.F. (2019). Using some biofertilizer treatments to promote growth and oil yield of rosemary (Rosmarinus officinalis L.). The Future Journal of Biology, 3:26-33.

Singh, M. and Guleria, N. (2013). Influence of harvesting stage and inorganic and organic fertilizers on yield and oil composition of rosemary (Rosmarinus officinalis L.) in a semi-arid tropical climate. Industrial Crops and Products, 42:37- 40 .

Sparks, D.L. (1996). Methods of Soil Analysis Part 3, Chemical Methods. Soil Science Society of America, American Society of Agronomy, USA, $1402 \mathrm{p}$.

Zahir, Z,A.; Arshad, M. and Frankenberger, J.W.T. (2004). Plant growth promoting rhizobacteria application and perspectives in agriculture. Adv. Agron., 81:96-168.

Zahir, Z.A; Munir, A.; Asghar, H.N; Shahroona, B. and Arshad, M. (2008). Effectiveness of rhizobacteria containing ACC-deaminase for growth promotion of peas (Pisum sativum) under drought conditions. J. Microbiol. Biotechnol., 18:958-63.

\section{دور الأسمدة الحيوية في تحسين انتاجية نبات إكليل الجبل تحت ظروف العجز المائي}

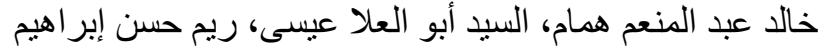

$$
\begin{aligned}
& \text { قسم بحوث النباتات الطبية و العطرية، معهد بحوث البساتين، مركز البحوث الزئيد الزراعية، الجيزة، مصر }
\end{aligned}
$$

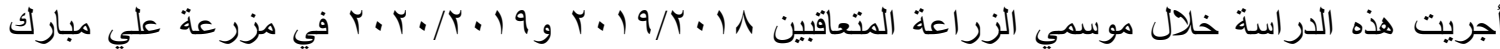

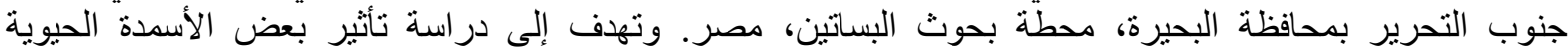

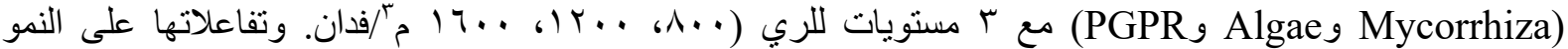

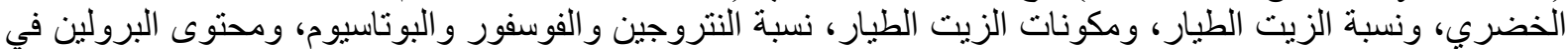

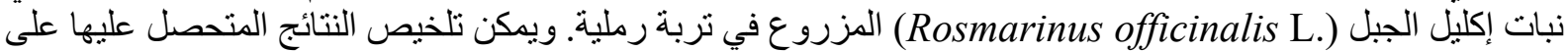

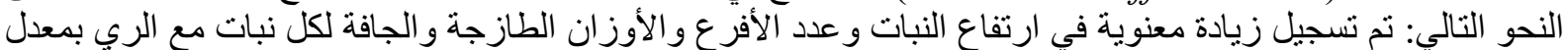

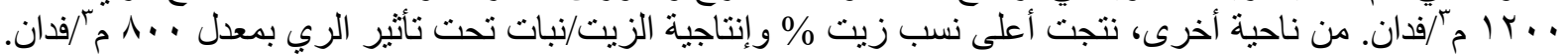

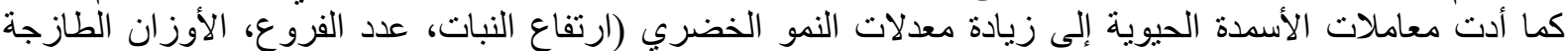

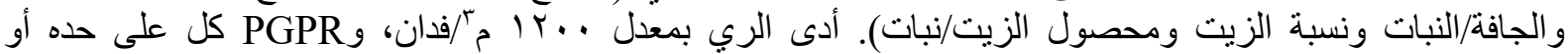

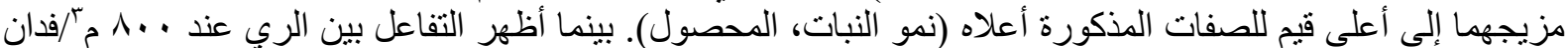

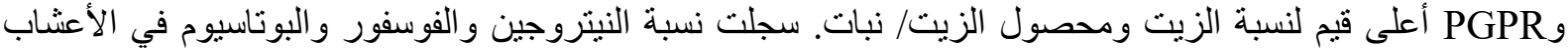




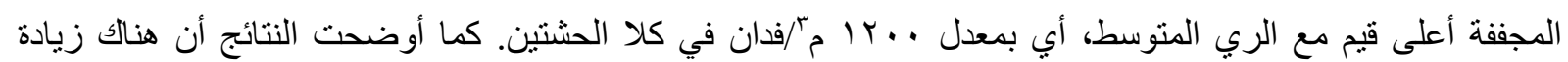

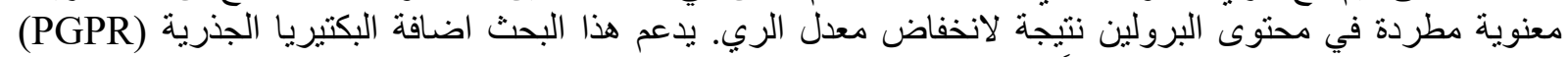

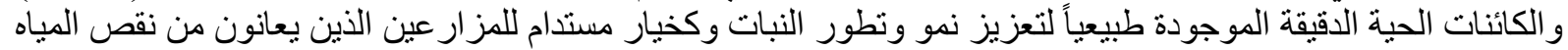
لزيادة إنتاجية نبات إكليل الجبل. 